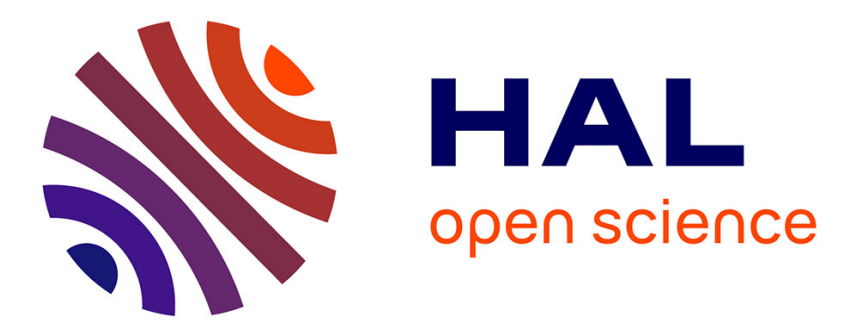

\title{
CMFDM: A methodology to guide the design of conceptual model of farmers' decision-making processes
}

Marion Robert, Alban Thomas, Jacques-Eric Bergez

\section{To cite this version:}

Marion Robert, Alban Thomas, Jacques-Eric Bergez. CMFDM: A methodology to guide the design of conceptual model of farmers' decision-making processes. 8. International Congress on Environmental Modelling and Software (iEMSs 2016), Jul 2016, Toulouse, France. hal-02739506

\section{HAL Id: hal-02739506 \\ https://hal.inrae.fr/hal-02739506}

Submitted on 2 Jun 2020

HAL is a multi-disciplinary open access archive for the deposit and dissemination of scientific research documents, whether they are published or not. The documents may come from teaching and research institutions in France or abroad, or from public or private research centers.
L'archive ouverte pluridisciplinaire HAL, est destinée au dépôt et à la diffusion de documents scientifiques de niveau recherche, publiés ou non, émanant des établissements d'enseignement et de recherche français ou étrangers, des laboratoires publics ou privés. 
Jul 12th, 3:30 PM - 3:50 PM

\section{CMFS: A Methodology to Guide the Design of Conceptual Model of Farmers' Decision-Making Processes}

Marion Robert

UMR 1248 AGIR, INRA, marion.robert@toulouse.inra.fr

Alban Thomas

Toulouse School of Economics

Jacques-Eric Bergez

UMR 1248 AGIR, INRA

Follow this and additional works at: https://scholarsarchive.byu.edu/iemssconference

Part of the Civil Engineering Commons, Data Storage Systems Commons, Environmental Engineering Commons, Hydraulic Engineering Commons, and the Other Civil and Environmental Engineering Commons

Robert, Marion; Thomas, Alban; and Bergez, Jacques-Eric, "CMFS: A Methodology to Guide the Design of Conceptual Model of Farmers' Decision-Making Processes" (2016). International Congress on Environmental Modelling and Software. 99.

https://scholarsarchive.byu.edu/iemssconference/2016/Stream-D/99

This Event is brought to you for free and open access by the Civil and Environmental Engineering at BYU ScholarsArchive. It has been accepted for inclusion in International Congress on Environmental Modelling and Software by an authorized administrator of BYU ScholarsArchive. For more 


\title{
CMFS: A Methodology to Guide the Design of Conceptual Model of Farmers' Decision-Making Processes
}

\author{
Marion ROBERT ${ }^{1}$ - Alban THOMAS ${ }^{2}$ - Jacques-Eric BERGEZ ${ }^{1}$ \\ 1 UMR 1248 AGIR, INRA, F-31326 Castanet-Tolosan, France, (marion.robert@toulouse.inra.fr) \\ ${ }^{2}$ Toulouse School of Economics, UMR 1081 LERNA, INRA
}

\begin{abstract}
:
The agricultural research community uses languages and approaches to model farmers' decisionmaking processes but does not clearly detail the steps necessary to build a decision model. We propose an original and easily applicable methodology for modelers to guide data acquisition and analysis, incorporate expert knowledge, and conceptualize decision-making processes in farming systems. It combines decision-making analysis with a modeling approach inspired by cognitive sciences and software-development methods. It is organized into four steps:
\end{abstract}

1) Problem Definition

- Specify the context and the initial research question.

- Chose the type of data to collect.

2) Case Study Selection

- Select case studies based on theoretical sampling approach to search for diversity instead of representativeness.

3) Data Collection and Analysis of Individual Case Studies

- Collect preliminary knowledge on the context domain.

- Select appropriate knowledge representations for the task.

- Use critical decision method to collect farmer's knowledge and identify critical incidents disrupting farming management.

- Present an initial transcription of the knowledge collected to the farmer for verification, refinement, revision.

- Represent farmers' knowledge with UML diagrams.

4) The Generic Conceptual Model

- List similarities and differences between individual analysis and UML graphs.

- Use literature, experts and modelers to strengthen development of the generic model by formulating and adding complex concepts.

- Format the generic conceptual model with UML graphs.

We applied the methodology to two research questions on water management, one in a developed country (France) and one in an emerging country (India). This methodology can be used in different contexts and will be a useful tool to guide modelers in building decision model in farming system.

Keywords: Decision-making; case-based analysis; cognitive task analysis; UML 